to train African investigators and research assistants. $(f)$ The Institute will publish the results of the research of its own officers or others working in similar fields.

In addition to the Director the staff of the Institute will include five anthropologists. One urban sociologist has been appointed and a second post in this field is contemplated. A linguistic post has been advertised and the appointment of a senior economist, a psychologist, and a legal expert are under discussion.

The following projects of research are contemplated in the near future:

(i) A social survey of Jinja to be started in 1950 .

(2) Anthropological studies in Buganda, Busoga, and Bunyankole, as well as tribal studies in the Lake Province of Tanganyika and in West Kenya which are under discussion. Cooperation with anthropologists at present studying the Alur, the Lugbara, the Acholi, the Turkana, and the Ambo, and with research workers shortly undertaking studies among the Kikuyu and the Teita, has been arranged.

(3) It is hoped that Dr. Tucker of the School of Oriental and African Studies will initiate linguistic studies at the Institute and will himself carry out a survey of some of the NiloHamitic languages.

The Institute is very anxious to accumulate information on the peoples of East Africa in the form of published work and unpublished manuscripts. The Director will be grateful for copies of unpublished material that members of the Government Service or Missionaries may have collected in the course of their work. Of particular value are historical accounts of tribal movements; data on social structure, clan organization, village organization, the family, marriage, age grades, \&c.; accounts of local cases or court procedure; data on modern economic conditions and on urban problems.

The Institute will also welcome offers of help on research problems from members of the Government Service or missionaries who have opportunities for making observations.

All inquiries should be addressed to the Director, East African Institute of Social Research, Makerere College, P.O. Box 262, Kampala, Uganda.

\title{
Regional Organization of Research in the Rhodesias and Nyasaland
}

IN October 1945 the Central African Council appointed a Special Committee on Joint Research to report on the steps to be taken to co-ordinate research in the three territories and in particular on the appointment of a Joint Director of Research. The Committee reported in November 1946 and recommended that a Central African Research Council should be set up with headquarters at Salisbury. The Council accepted the recommendation in principle, but deferred action pending the results of a survey of Central African Research. The Survey was carried out in 1947-8 by Dr. J. E. Keyston, whose report was submitted to the Central African Council in September 1948. ${ }^{3}$ Dr. Keyston travelled widely through the Rhodesias and Nyasaland, visited neighbouring territories, and had a great number of discussions with scientists, officials, and with representatives of many cross-sections of the community. $\mathrm{He}$ concludes that much more research should be undertaken, that more centralized organization is needed, that the conditions of service for research scientists are not satisfactory, and that arrangements for ensuring the supply of scientific manpower are inadequate. He considers, however, that the support and control of research are too exclusively governmental and that there is insufficient co-operation with other countries. He suggests that, though many of these deficiencies could be remedied to some extent by separate action in each territory, a more far-reaching improvement could be effected through co-operative action and that an essential element in the machinery required for collaboration in research is a joint

I Regional Organisation of Research in the Rhodesias and Nyasaland: A Report to the Central African Council, by Dr. J. Keyston, O.B.E., D.Phil., B.Sc., F.Inst.P., Salisbury, 1949, Pp. 91. ss. 
Research Council. In part II of his Report Dr. Keyston gives an outline of the constitution and functions of such a Research Council. He suggests that the Council should be a corporate body set up by legislation and, while it should be responsible to the Governments of the territories and receive a capital endowment as well as annual votes, it should be empowered to receive donations from other sources, to appoint its own Executive Committee, specialist committees, and research staff, and that at least half its members should be unofficial. Part III is devoted to a survey of research requirements of the Rhodesias and Nyasaland in which joint action can be recommended. This section is concerned mainly with such topics as agricultural, geological, hydrological, medical, and veterinary researches, but also includes proposals for sociological and anthropological research, which, it is suggested, should be built up around the Rhodes-Livingstone Institute, with the proviso, however, that the headquarters of the Institute should be moved to Salisbury. An interesting suggestion is made that sociological research should be linked up with Development Centres such as those established in Northern Rhodesia as part of the ten-year development plan; a further suggestion envisages the formation of a Central African Sociological Research Centre, by means of which 'sociologists . . . can be attached for short or long periods to any department of Government, any investigational team, any private industry, any activity in which the African becomes deeply involved'. 'Sociology', concludes Dr. Keyston, 'pervades the applicational end of all plans for progress and development in Central Africa. One cannot define crisply what the sociologist will contribute to the application of new knowledge and legislation ... but we can be sure that without the expert we shall have more difficulty than we need.'.

\section{The Human Geography of Inter-tropical Africa}

A Research Committee of the British Association for the Advancement of Science was established in 1926 to encourage the study of the human geography of inter-tropical Africa. At that time there were few trained geographers in Africa, and the Committee was mostly concerned with the collection of information from government officers, anthropologists, missionaries, and others. A pamphlet, 'The human geography of inter-tropical Africa', was prepared and was widely circulated. Special attention was drawn to the questionnaire contained in it, and the response was very good from some territories, notably from Northern Rhodesia. Professor A. G. Ogilvie, then Secretary of the Committee, devoted the bulk of his presidential address to Section E (Geography) of the British Association in 1934 to an analysis of the human geography of Northern Rhodesia on the basis of the replies received to the questionnaire (also published in the Scottish Geographical Magazine, so (1934), pages $353-78$ ).

At the Newcastle-upon-Tyne meeting of the British Association in 1949 the Committee was reconstituted under the chairmanship of Professor Ogilvie, with R. W. Steel as Secretary. The other members are Professors Frank Debenham and Daryll Forde, Dr. R. J. Harrison Church, and Mr. D. B. Mather. The Committee believes that there is room for some co-ordination between those who are interested in the human geography of Africa, whether they are resident in the tropics or in the United Kingdom; and it hopes that more progress may be possible than in the period before the war, especially because of the establishment of departments of geography at Makerere and Ibadan, and in the University College of the Gold Coast, and of institutions such as the Rhodes-Livingstone Institute in Northern Rhodesia. Moreover, many more anthropologists are now at work in the field and are concerned to record material on the significance of the physical environment. Great progress has also been made in the topographical mapping of the colonies during recent years.

As a first step the Committee is anxious to make contact with all persons in tropical 